\title{
Implementation of CNG as an Alternative Fuel for Automobiles in Nigeria: Benefits and Recommendations
}

\author{
Ikechukwu Obiuto Ibeneme \\ Department of Petroleum and Gas Engineering \\ University of Port Harcourt \\ Port Harcourt, Nigeria
}

\author{
Joshua O. Ighalo \\ Department of Chemical Engineering \\ University of Ilorin \\ Ilorin, Nigeria
}

\begin{abstract}
In an attempt to address major causes of pollution from gas flaring and transportation, the Nigerian government introduced the use of CNG (compressed natural gas) as an alternative fuel for automobiles in 1997. However, progress has been very slow as the government has concentrated more on LNG (liquefied natural gas) exportation, LPG (liquefied petroleum gas), and gas to power projects. These projects have aided in reducing gas flaring, but pollution from transportation is still increasing. This article provides an extensive review of the benefits and recommendations to foster the use of CNG as an alternative fuel for automobiles in Nigeria. The use of CNG as an alternative fuel for automobiles in Nigeria has benefits ranging from reduction in pollution to an increase in productivity, efficiency, safety, and energy security. Thus, to encourage the use of CNG as automobile fuel in Nigeria, the government needs to develop a targeted carbon tax system, favourable market-based policies and natural gas transmission and distribution network; increase availability and access to CNG refuelling stations and public awareness; subsidise vehicle conversion expenses; begin with bi-fuel/dual-fuel automobiles; assign responsibilities; reform gas pricing; partner with automobile producers in Nigeria.
\end{abstract}

Keywords - CNG; alternative fuel; flaring; transportation; Nigeria

\section{INTRODUCTION}

Nigeria has the largest proven natural gas reserve in Africa and the 8th largest in the world with a total of $5,675 \mathrm{bcm}$ (billion cubic metres) (200.41 trillion cubic feet) [1]. The Nigeria National Petroleum Corporation (NNPC) reported that about $51 \%$ of associated gas produced was flared between 1990 and 2010. This is equivalent to 53 billion litres gasoline, which is more than 14.5 years worth of gasoline consumption in Nigeria [2]. In the past, Nigeria has always been secondworst gas flaring country after Russia [3]. However, Nigeria is finally realizing the potential of natural gas. It is no longer seeing it as a by-product of flaring [4]. Hence, Nigeria has made great progress in cutting down gas flaring by $18 \%$ since 2013 (Fig. 1), to less than 8 billion cubic metres in 2015 [5]. A total of 2,836.55 bcf (billion cubic feet) of Natural Gas was produced in Nigeria during the year 2018. Of the natural gas produced, 2,554.47 bcf $(90.06 \%)$ was utilized, while 282.08 bcf $(9.94 \%)$ was flared [6]. Though the percentage of flaring has reduced, Nigeria still ranks among the top ten countries flaring gas in 2018 (Fig. 2). Also, Natural gas production remains low even with the large reserves. PWC estimates that Nigeria economy lost N233 billion to gas flaring in 2018. And the environmental cost to Nigeria amounts to N28.8 billion annually [7].

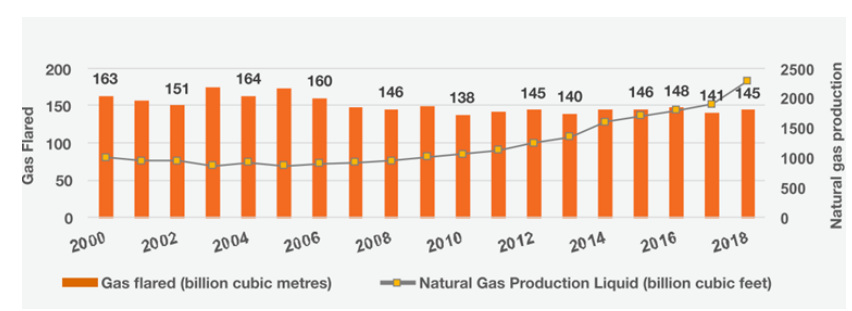

Fig. 1. The gas produced and flared in Nigeria [7].

Though Nigeria ranks currently as the 8th country in terms of her gas reserve, its gas reserves are still very much underused. At the current rate of utilization, the natural gas reserve in Nigeria would last for over 100 years [8]. Also, gas flaring has led to environmental pollution, community relocation, health and safety issues, and economic loss [9]. Therefore, the best practice for the Nigerian government is the monetization of natural gas as it would have both economic and environmental benefits [10].

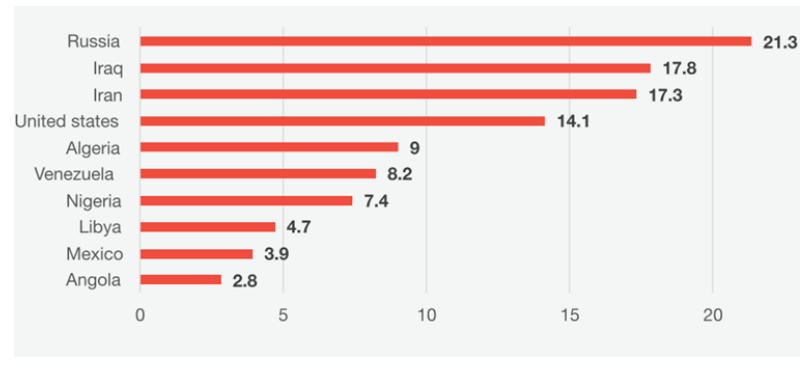

Fig. 2. Top ten countries flaring gas in 2018 (billion cubic feet) [7].

Nigeria has put in a lot of effort to abate gas flaring, and this has aided in reducing gas flaring to $9.94 \%$ by 2018 [6]. In 2008 , the Nigeria gas master plan was approved to help utilize and manage gas resources in Nigeria [11]. Other policies to help abate gas flaring include; Nigeria Gas Flare Commercialization (2017), and Associated Gas Re-injection Act (1979) [7]. All these assisted in the reduction of gas flaring yearly. The transport sector is another major contributor to pollutant emission and energy consumption all over the world. In an attempt to address the problems of gas 
flaring, transport energy shortage, and high emission from the transportation sector, the government introduced the use of CNG as automobile fuel in 1997. Nigeria has improved its gas utilization capacity through projects in liquefied natural gas (LNG), gas to liquids (GTL), natural gas to power, and compressed natural gas (CNG) [12]. If $\mathrm{CNG}$ is used in transportation, it can lead to urban air improvement, reduction in adverse health, and social effects [13]. The use of CNG as automobile fuel is geared towards sustainable transportation. And CNG is to benefit from Nigeria's reserves of natural gas.

Igbojionu et al. [14] did a technical and economic analysis of using CNG as fuel for public transportation. The Port Harcourt - Onitsha express road was used as a case study. In the analysis, they considered the cost of designing and laying gas pipeline networks for gas gathering and supply to the CNG refuelling stations, the cost of CNG refuelling stations, and the cost of CNG vehicles. The study observed that although a high capital investment was required mainly from purchasing $\mathrm{CNG}$ vehicles and building $\mathrm{CNG}$ refuelling stations, it would be both technically and economically viable to use CNG as fuel for public transportation in Nigeria. From the analysis, it took less than 5 years to break even. This analysis agrees with analysis earlier conducted by Anyadiewu et al. [15] who also concluded that CNG as automobile fuel in Nigeria is economically viable.

Within the scope of the authors' search, no review has been published addressing the nexus of gas utilization and the transportation industry, and discussing specific benefits with viable recommendations. This study hopes to fill this gap in knowledge. This article presents an extensive review of the benefits and recommendations to foster the use of $\mathrm{CNG}$ as an alternative fuel for automobiles in Nigeria. CNG is compared with the conventional fuel (gasoline and diesel) used in Nigeria.

\section{THE TRANSPORTATION SECTOR AND THE DEMAND FOR ALTERNATIVE ENERGY}

The transport sector is a major contributor to pollutant emission and energy consumption all over the world. In 2007, the transport sector accounted for the second-largest share in $\mathrm{CO}_{2}$ emission (22.9\%) worldwide. With a subsequent increase in car demand and population growth, the emission would also increase [16]. In Nigeria, 94\% of people experience pollution levels far above World Health Organization guidelines and also higher than the $72 \%$ for sub-Saharan Africa as a whole [17]. The transportation sector is responsible for $10 \%$ of greenhouse gases nationally and $30 \%$ of fossil fuel consumed [18]. Emission from automobiles is a major source of environmental pollution in Nigeria [19]. The pollution from transportation greatly affects life on earth and this pollution would continue to increasing except actions are taken. Future energy demand projection for transportation in Nigeria shows a steady increase in energy demand (see Fig. 3). Most likely this increase is due to high population growth, urbanisation, and increased per capita incomes. This inadvertently leads to more cars in the country as observed by the steady rise in recent years (Fig. 4). This increase in energy demand in transportation due to more available cars would imply higher pollution, so there is a need for an alternative cleaner fuel [20]. However, currently,
Nigeria depends mainly on gasoline and diesel as fuel for automobiles [21].

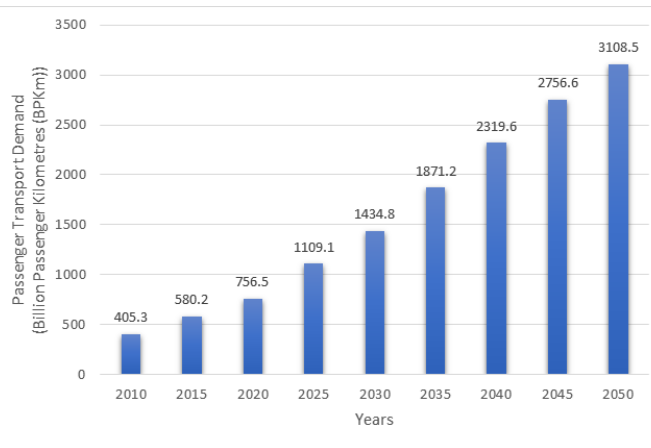

Fig. 3. Projection of energy demand in Nigeria passenger transportation [20]

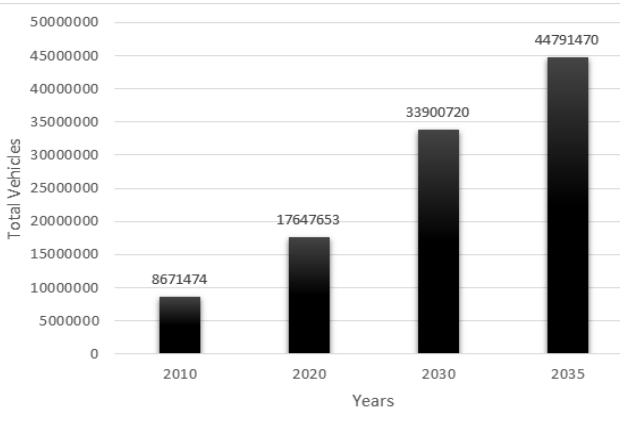

Fig. 4. Nigeria vehicle forecast, 2010-2035 [22]

Any little increase in $\mathrm{CO}_{2}$ emission from human activities has a destabilizing effect globally, as an increase in $\mathrm{CO}_{2}$ emission leads to an increase in temperature which results in increased emission from natural sources leading to increased occurrence of natural disasters [23]. There is a steady rise in $\mathrm{CO}_{2}$ emissions in Nigeria due to the transport sector (Fig. 5). Thus, there is a need for Nigeria to cut down emissions especially in densely populated cities. As advised by Intergovernmental Panel on Climate Change (IPCC), there is a need to cut down greenhouse gas emissions by 50 to $80 \%$ by 2050 to affect the high effects of global warming [24]. Certainly, Nigeria needs to properly utilize its vast gas reserve, because concentrating alone on cooking gas would be only able to absorb about $5 \%$ of flared gas. Nigeria needs to expand its gas utilization in power and fuel for automobiles [25].

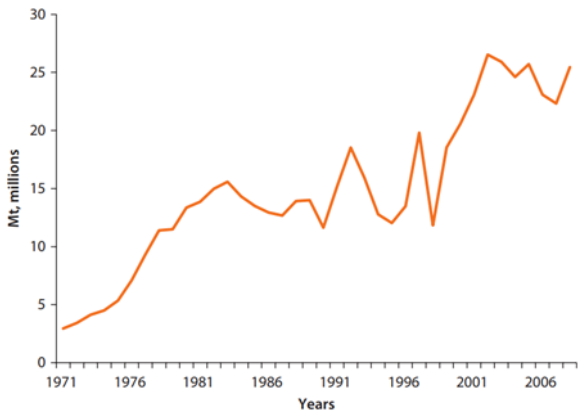

Fig. 5. Transport sector $\mathrm{CO}_{2}$ emissions time series [22]. 
In an attempt to address the problems of gas flaring, transport energy shortage, and high emission from the transportation sector, the government introduced the use of CNG as automobile fuel in 1997. However, despite a proposal by the government to adopt the use of CNG as automobile fuel in 1997, adaptation has been very slow. Nigeria has mainly focused on gas exports and gas to power [2], [26]. There were predictions that by 2020 natural gas use as fuel would be popular in Nigeria [4]. However, though we have seen great growth in LNG and LPG [11], the reverse has been the case for $\mathrm{CNG}$.

CNG is produced by compressing natural gas (mainly made of methane gas) to less than $1 \%$ of the original volume it occupies at standard atmospheric pressure. $\mathrm{CNG}$ is stored at a pressure of $200-248$ bar $(2900-3600$ psi), in metallic cylindrical containers [27]. A lot of persons confuse CNG for LNG, however, they are both different. The major difference is that $\mathrm{CNG}$ is stored as a gas at very high pressure while LNG is stored at cryogenic temperatures. CNG being cheaper and easier to store as it does not require complex equipment [24]. The use of CNG as fuel for automobiles was first known as far back as early 1930 in Italy [28]. From 1995 - 2015 we witnessed an annual growth of $24 \%$ as shown in Fig. 6 [27].

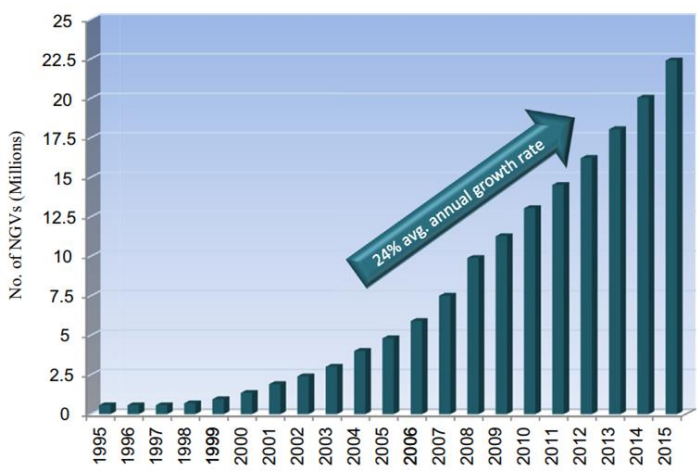

Fig. 6. Worldwide growth of NGV's between 1995 - 2015 [27].

Even though there has been a global growth in NGV's (natural gas vehicles), it is however sadly noted that this growth does not reflect what is happening in Africa. Africa is finding it difficult to adopt this innovative trend of NGV's [27]. Nigeria has improved its gas utilization capacity through projects in liquefied natural gas (LNG), gas to liquids (GTL), natural gas to power, and compressed natural gas (CNG) [12], however, as at 2016 Nigeria only had 6,000 CNG automobiles [29] in comparison to about 11.7 million registered cars in Nigeria [30]. This is only about $0.051 \%$ of cars running on CNG in Nigeria. Hence more needs to be done as regards the use of $\mathrm{CNG}$ as an alternative fuel to gasoline and diesel. If $\mathrm{CNG}$ is used in transportation, it can lead to urban air improvement, reduction in adverse health and social effects [13]. The use of CNG as automobile fuel is geared towards sustainable transportation. CNG is to benefit from Nigeria's reserves of natural gas.

\section{BENEFITS OF CNG AS AN AUTOMOBILE FUEL IN NIGERIA}

\section{A. Reduction in Air Pollutant and Noise Pollution from the Transport Sector}

Automobiles that use gasoline and diesel emit air pollutants and air particles that are very dangerous to human health. These pollutants can increase the risk of developing stroke, heart failure, myocardial infarctions, respiratory diseases, cancer, etc. Hence there is a need for an alternative fuel with fewer air pollutants than gasoline and diesel [20]. Oluwole et al. [18] observed that there are very high concentrations of emission of $\mathrm{HC}$ (hydrocarbon), $\mathrm{O}_{2}$ and $\mathrm{NOx}$ (nitrogen oxides) in Lagos roads and suggested that a fuel switch to CNG would be the best for the environment. CNG as fuel has great environmental potential as there is a reduction in air pollutants emission when it is used as fuel [31].

In comparison to gasoline and diesel, $\mathrm{CNG}$ has a reduced $\mathrm{CO}_{2}$ emissions [32] by $23 \%-35 \%$, almost zero particulate matter (PM) emissions, $87 \%$ - 90\% reduction in NOx emissions, and $67 \%$ - 76\% reduction in $\mathrm{HC}$ emissions [33]. This is also close to Haeng \& Mahmud [34] values, which stated that there is a significant reduction in the emission of CO by $70 \%$, non-methane organic gas by $87 \%$, NOx by $87 \%$ and $\mathrm{CO}_{2}$ by $20 \%$.

A study of both Delhi and Brazil has significantly shown how the use of CNG automobiles can cut down emissions. These places showed a drastic reduction in air pollutants from the time they adopted the use of CNG automobiles [35], [36]. Also, further study of Dhaka shows that the use of CNG as automobile fuel can greatly improve air quality and reduce premature death [37]. Additionally, CNG automobiles make less noise than gasoline and diesel automobiles [27]. This implies a reduction in noise pollution when $\mathrm{CNG}$ automobiles are used instead of conventional fuel automobiles.

\section{B. Energy Security}

An alternative transportation fuel of low carbon emission would increase energy security [20]. This is very likely as there would not be much dependence on conventional gasoline and diesel in Nigeria. Especially since oil prices are very volatile and there is also an occasional scarcity of oil supply [38]. In Nigeria, the gasoline market is very volatile and we often experience scarcity of products some times. During these times, gasoline is usually sold at a very high price and this affects the cost of every other thing, making it more difficult for Nigerians to survive. This scarcity is most felt by the automobile sector, therefore the use of CNG as an alternative fuel for automobiles would greatly abate the effect of the volatile gasoline market in Nigeria [39]. Certainly, with the increasing demand for transportation, there is a need for cleaner alternative transportation and $\mathrm{CNG}$ is one of the best for Nigeria.

\section{Increased Productivity}

Energy is an important factor for socio-economic development, therefore, with an alternative fuel of low-carbon emission, productivity would increase. Transportation would also be cheaper and people would find it easier to move around [20]. Also, as noted by Olufemi O. Ogunlowo et al. 
[40] and Ubani \& Ikpaisong [39], since CNG is locally gotten unlike gasoline and diesel that is mostly imported, it has the potential to conserve foreign reserve in Nigeria. This is because less amount of money would be spent on the importation of gasoline and diesel.

\section{Cheaper Based on Energy Content}

Both Giwa et al. [41] and Muhammad Imran Khan et al. [27] observed that $\mathrm{CNG}$ is cheaper than gasoline and diesel with a cost reduction of about $76.8 \%$ (gasoline) and $62.9 \%$ (diesel). Certainly, both cost and emission would be reduced with the substitution of $\mathrm{CNG}$ for conventional fuel. In Armenia, CNG is 3-4 times cheaper than gasoline and half the price of diesel [42]. Economic analysis has shown that a car that covers an average distance of $100 \mathrm{~km}$ daily, saves up to $\mathrm{N}$ (Naira)1,143 daily and N34,284 monthly when compared with cars running on gasoline. This means there would be a total saving of $\mathrm{N} 411,408$ in a year [39]. It is possible for Nigeria to save up to N654 billion yearly if the use of CNG as fuel is properly implemented [43].

\section{E. Increased Automobile Efficiency}

CNG has a high octane number, making it less likely to need antiknock additives, such as benzene and lead [44]. Also, this feature means $\mathrm{CNG}$ has a higher heat of combustion and lower emission [23]. This makes CNG engines superior in performance than gasoline and diesel engines. CNG automobiles have an additional service year of $2-3$ years in comparison to conventional fuel automobiles. This is due to it being a cleaner fuel, which leads to lower routine maintenance [26]. CNG automobiles have more efficient engines, longer-lasting spark plugs, and reduced routine oil change [39]. Also, the brake thermal efficiency of $\mathrm{CNG}$ is between $5-12 \%$ higher than that of gasoline automobiles [27]. The brake thermal efficiency is used to measure the conversion rate of heat to mechanical energy [45]. Therefore, CNG having a higher thermal efficiency implies it would convert more heat to mechanical energy than gasoline.

\section{F. CNG Automobiles are Safer}

CNG is less combustible than gasoline and can only ignite between $5 \%$ to $15 \%$ concentration in air. Also, it requires high compression energy and a high ignition temperature of $680{ }^{\circ} \mathrm{C}$ in comparison to the gasoline of $230-280^{\circ} \mathrm{C}$ [26]. $\mathrm{CNG}$ cylinders are also more durable than gasoline and diesel tanks, therefore they are less likely to be affected by automobile accidents [46]. Also, CNG being a gas means it just disappears into the air when there is a leakage instead of leading to a pool of fuel like gasoline, therefore reducing its probability to cause a fire outbreak when there is a leakage [27].

\section{RECOMMENDATIONS FOR CNG IMPLEMENTATION AS AN AUTOMOBILE FUEL IN NIGERIA}

\section{A. Developing a Targeted Carbon Tax System}

It has been observed that carbon tax can mitigate $\mathrm{CO}_{2}$ emissions by about $26.9 \%$ by 2050 in Nigeria [20]. Carbon tax policies would increase the cost of gasoline and diesel while lowering the cost of alternative fuel like CNG. Nigerians would be forced to purchase vehicles that run on $\mathrm{CNG}$, as they would be more economically viable. Also, just like in India where emissions from gasoline for each city were measured regularly and cities with high gasoline emissions where forced by court orders to switch to better alternatives like $\mathrm{CNG}$ automobile [47], Nigeria can also adopt such strategy, forcing cities with high carbon emission to switch to $\mathrm{CNG}$ as automobile fuel.

\section{B. Increase Availability and Access to CNG Refuelling Stations}

Undoubtedly availability and access to $\mathrm{CNG}$ refuelling stations is a very important factor in the development of $\mathrm{CNG}$ as an alternative fuel for automobiles. Studies indicated that CNG refuelling stations equivalent to at least $10 \%$ to $20 \%$ of gasoline and diesel refuelling stations would be enough for prospective adaptors not to see the unavailability of CNG refuelling stations as a hindrance to switching [34]. A major way of increasing CNG refuelling stations is by easing the bureaucracy in CNG refuelling stations construction and operation. Permits for CNG refuelling stations and operations should be far cheaper than those for conventional fuels, this would encourage more private investors to construct and operate CNG refuelling stations [34]. The government use of its NNPC mega station scheme to construct CNG refuelling stations in strategic positions around the country has been suggested [26]. Also, an introduction of a Mobile CNG refuelling station would increase accessibility. Furthermore, a lot of Nigerian banks cannot give loans to indigenous companies willing to invest in CNG refuelling stations, and the alternative of getting these loans abroad is not favourable especially because of the volatility of the naira [40]. The government can provide loans to $\mathrm{CNG}$ refuelling station investors with attractive interest rates.

\section{Better Market-Based Policies for CNG as Automobile Fuel}

The government should introduce subsidies to reduce the cost of CNG and also further widen the gap between $\mathrm{CNG}$ and conventional fuel. These subsidies include a reduction in importation tax for CNG production machinery and equipment, accessories for automobile conversion, sales taxes and operational tax on CNG refuelling stations [34]. O.O. Ogunlowo et al. [2] showed that government incentive helps promote CNG use as an alternative fuel. However, this is not the case in Nigeria as there is no known incentive for investors to take advantage of the CNG market and promote CNG automobiles. For example, in Pakistan, custom duty and tax exemption are major factors that encouraged corporations to invest in the CNG programme. However, it is bad for the CNG programme to excessively depend on subsidies as this could affect its future development [26]. When investors see that there are a high return and less risk in CNG investment, they would be more willing to invest.

\section{Subsidising Vehicle Conversion Expenses}

The provision of loans and subsidies for vehicle conversion from gasoline/diesel to $\mathrm{CNG}$ would motivate more persons to convert their automobiles from gasoline/diesel to CNG [34]. Certainly, it would be difficult for a lot of Nigerians to afford the conversion cost, so the government can partner with banks to offer interest-free loans for automobile 
conversion. Also, the cost of conversion should be subsidized to encourage more persons to convert [2].

\section{E. Commence with Bi-Fuel/Dual-Fuel Automobile}

Most passenger CNG vehicles can either be dedicated CNG or bi-fuel. Bi-fuel vehicles can run on both CNG and gasoline. Many have a range of $400 \mathrm{~km}$ on CNG mode and $1000 \mathrm{~km}$ on gasoline mode. While commercial CNG vehicles can either be dedicated CNG or dual-fuel. The dual-fuel vehicles could displace up to 50-60\% of the diesel fuel [32], [34]. Nigeria should begin with bi-fuel/dual-fuel automobiles instead of only CNG dedicated automobiles, as these better handle the con of CNG automobiles which is its low range and frequent refuelling [2]. This strategy was adopted in Pakistan and it worked [48]. Also, it is discovered that dual-fuel engines are $30-40 \%$ more efficient than a conventional vehicle. It also has the ability of abating fuel consumption by $25 \%$ [27]

\section{F. Assignment of Responsibilities Regarding the Implementation of $\mathrm{CNG}$ as an Alternative Fuel}

A study of all countries that have successfully implemented CNG as an alternative fuel shows there was an assignment of important responsibility as regards the development of CNG. India, Argentina and Brazil have agencies set up to promote $\mathrm{CNG}$ use as fuel. However, in Nigeria, there is no specific agency for $\mathrm{CNG}$ implementation as vehicle fuel [2], [26]. Olufemi O. Ogunlowo et al. [40] showed that Nigeria is keener on the reduction of gas flaring than gas utilization. This has led to little or no policies on gas utilization. Also, a lot of the companies prefer gas re-injection than gathering and distributing for proper gas utilization such as CNG automobile development. A CNG programme should be created with the responsibility of market development shared among them, from the development of CNG refuelling stations to $\mathrm{CNG}$ automobile provision.

\section{G. Development of natural gas transmission and distribution network}

The success of countries like Argentine and Pakistani is partly due to their strong Gas transmission and distribution network. It is also noticed that in Brazil higher priority is given to the development of the domestic gas network. However, this is not the case in Nigeria as a higher priority is given to international network development [2]. This can be seen from the WAGP (West African Gas Pipeline) and NLNG (Nigerian Liquefied Natural Gas) export terminals which were developed ahead of domestic networks [26]. The domestic gas sales are relatively poor in comparison with export. CNG is attractive to investors if the distance to the market is around $500-2500 \mathrm{~km}$ [8]. Therefore, Nigeria needs to develop its domestic gas transmission and distribution networks as this would simulate the construction of more $\mathrm{CNG}$ refuelling stations. The cost of using CNG transport trucks is higher than using pipelines [49], therefore it would be more cost-friendly to develop natural gas transmission and distribution networks.

\section{H. Increase Public Awareness on the Benefits of CNG Automobile}

The majority of the general public in Nigeria has never heard of CNG automobiles. Therefore, the government needs to provide public awareness as regards the environmental and economic benefits of using $\mathrm{CNG}$ in comparison to conventional fuels [2]. Unlike LPG for cooking, CNG automobile has had little or no public awareness in Nigeria [40]. As noted by Abbanat [50], the best way to increase the customer's response to CNG automobiles is through public awareness. The government can create awareness through skill acquisition programs. This would be an opportunity to train people in various skills needed to maintain and use $\mathrm{CNG}$ automobiles. This development would reduce unemployment and increase the indigenous workforce in the $\mathrm{CNG}$ automobile sector in Nigeria [51].

\section{Price Reform}

The pricing for gas needs a total reform as it is observed that the domestic wholesale price is far lower than the export price, therefore encouraging the export of gas. The government needs to analyse the pricing system and reform it to favour all markets [26]. This would also cut down the flaring of gases as companies would see gas as being profitable.

\section{J. Partnership with Indigenous Automobile Producers to Manufacture Affordable CNG Automobiles}

As noted by Olufemi O. Ogunlowo et al. [40], there is a higher cost for $\mathrm{CNG}$ vehicles in comparison to conventional fuel vehicles in Nigeria. Also, the cost is higher in comparison to $\mathrm{CNG}$ vehicles in other countries. This is mainly due to the high import dependence of Nigeria. Just like India [47], Nigeria's government needs to partner with indigenous vehicle producers such as Innoson Vehicle Manufacturing Company (IVM), Limited, Nnewi, Anambra, Nigeria [52]. This would reduce the cost of $\mathrm{CNG}$ vehicles, making them more affordable. Research and development in CNG automobile manufacturing in Nigeria should also be funded by the Nigerian government. This would help in optimizing the already established CNG automobile designs specifically for Nigeria.

\section{K. Prioritization of CNG Transit Buses Over Other Technologies}

The government needs to focus more on developing commercial transit buses to run mainly on $\mathrm{CNG}$. This development would reduce both emissions and traffic drastically. The majority of these transit buses in the city are owned by the government, therefore the government can easily implement this recommendation. Also, this strategy was implemented in china and it helped china develop its gas utilization sector through CNG usage as fuel in buses [53], and due to transit buses being more profitable with $\mathrm{CNG}$ as fuel, more person would be willing to invest in it and the government would make more revenue from their investment.

\section{Use of CNG Automobiles in Highly Populated Cities}

Urban and highly populated cities are a major market for CNG automobiles, as these cities have high levels of noise and harmful emissions from transportation. These highly populated cities are also likely the most polluted too. Therefore, the use of CNG automobiles in highly populated cities would abate both emission and noise pollution [23]. This strategy was very effective in India. Orders for mandatory use of CNG automobile was extended to cities with 
high pollution. This helped cut down pollution in many cities in India [47].

\section{CONCLUSION}

This article provided an extensive review of the benefits and recommendations to foster the use of $\mathrm{CNG}$ as an alternative fuel for automobiles in Nigeria. To solve the twin problem of gas flaring and pollution from the transportation sector in Nigeria, the use of alternative fuel (CNG) is recommended. The use of $\mathrm{CNG}$ as an alternative fuel for automobiles in Nigeria has benefits ranging from reduction in pollution to an increase in productivity, efficiency, safety and energy security. However, Nigeria is far behind in its realization of adapting CNG as an alternative fuel. To achieve her objectives in $\mathrm{CNG}$ adaptation, the following were recommended; developing a targeted carbon tax system, increase availability and access to $\mathrm{CNG}$ refuelling stations, better market-based policies for $\mathrm{CNG}$ as automobile fuel, subsidising vehicle conversion expenses, commence with bifuel/dual-fuel automobile and assignment of responsibilities as regards the implementation of $\mathrm{CNG}$ as an alternative fuel. Other recommendations include the development of natural gas transmission and distribution network, increase public awareness on the benefits of CNG automobiles, price reform, partnership with automobile producers in Nigeria to produce affordable CNG automobiles, prioritization of CNG transit buses over other technologies and use of CNG automobiles in highly populated cities.

\section{REFERENCES}

[1] OPEC, "OPEC Annual Statistical Bulletin," 54th edition, 2019.

[2] O. O. Ogunlowo, A. L. Bristow, and M. Sohail, "Understanding the barriers to the use of compressed natural gas as an automotive fuel in Nigeria: lessons from international markets,” NGV Transp. Mag., 2016.

[3] A. Oniwon, "Gas utilization for long term clean energy and economic growth,” SPE Conf. NAICE, 3rd August, 2011.

[4] U. Osokogwu and J. A. Ajienka, "Natural gas as an alternative fossil fuel; the prospect and the market in 2020," SPE Niger. Annu. Int. Conf. Exhib., 2012

[5] "New data reveals uptick in global gas flaring," World Bank, 2016 https://www.worldbank.org/en/news/press-release/2016/12/12/newdata-reveals-uptick-in-global-gas-flaring\#: :text=Russia remains the world's largest,over the last several years.

[6] NNPC, "2018 Annual Statistical Bulletin,” ASB 1st Edition, 2018

[7] PWC, "Assessing the impact of gas flaring on the Nigeria economy," PricewaterhouseCoopers Limited, 2019.

[8] C. A. Odumugbo, "Natural gas utilisation in Nigeria: challenges and opportunities," J. Nat. Gas Sci. Eng., vol. 2, no. 6, pp. 310-316, 2010 , doi: 10.1016/j.jngse.2010.08.004

[9] K. I. Idigbe and P. N. Onwuachi-Iheagwara, "Optimizing natural gas assets from marginal fields in Nigeria," J. Sci. Multidiscip. Res., vol. 10 , no. 3, pp. 49-64, 2018

[10] K. I. Idigbe, "Driving sustainable growth through natural gas assets in Nigeria,” J. Emerg. Trends Eng. Appl. Sci., vol. 5, no. 2, pp. 140-147, 2020.

[11] A. A. Carim and M. Onyekonwu, "Review of gas resource utilization using applicable technologies: a case study of Nigeria," Int. J. Eng. Sci., vol. 5, no. 3, pp. 71-78, 2016.

[12] C. Nwaoha and D. A. Wood, "A review of the utilization and monetization of Nigeria's natural gas resources : Current realities," J. Nat. Gas Sci. Eng., vol. 18, pp. 412-432, 2014, doi: 10.1016/j.jngse.2014.03.019.

[13] M. I. Khan, T. Yasmin, and A. Shakoor, "International experience with compressed natural gas ( $\mathrm{CNG}$ ) as environmental friendly fuel," Energy Syst., vol. 6, no. 4, pp. 507-531, 2015, doi: 10.1007/s12667015-0152-x.
[14] A. Igbojionu, C. Anyadiegwu, E. Anyanwu, B. Obah, and C. Muonagor, "Technical and economic evaluation of the use of CNG as potential public transport fuel in Nigeria," Sci. African, vol. 6, p. e00212, 2019, doi: 10.1016/j.sciaf.2019.e00212.

[15] C. I. C. Anyadiegwu, N. P. Ohia, and C. M. Muonagor, "Economic analysis of utilising compressed natural gas ( $\mathrm{CNG}$ ) as vehicular fuel in Nigeria,” Int. J. Sci., vol. 6, no. 9, 2017, doi: 10.18483/ijSci.1405.

[16] B. Peng, H. Du, S. Ma, Y. Fan, and D. C. Broadstock, "Urban passenger transport energy saving and emission reduction potential : A case study for Tianjin , China,” Energy Convers. Manag., 2015, doi: 10.1016/j.enconman.2015.01.017.

[17] IEG, "Project performance assessment report Nigeria Lagos urban transport project," Independent Evaluation Group , World Bank Group, no. 103068,2016

[18] A. F. Oluwole, O. H. Joshua, O. Oyediran, S. Guttikunda, and O. I Asubiojo, "Prognosis of emission limits and regulations for vehicular emission pollutants in Nigeria," vol. 2, no. August, pp. 1-11, 2019.

[19] A. Odogun and P. Georgakis, "Transport pollution: A research of the Nigerian transport sector,” Int. J. Innov. Technol. Explor. Eng., vol. 8 , no. 11S, pp. 492-497, 2019, doi: 10.35940/ijitee.K1083.09811S19.

[20] M. O. Dioha and A. Kumar, "Sustainable energy pathways for land transport in Nigeria," Util. Policy, vol. 64, no. August 2019, p. 101034 2020, doi: 10.1016/j.jup.2020.101034

[21] H. Gujba, Y. Mulugetta, and A. Azapagic, "Passenger transport in Nigeria: environmental and economic analysis with policy recommendations.," Energy Pol., vol. 55, pp. 353-361, 2013, doi https://doi.org/10.1016/J.ENPOL.2012.12.017.

[22] R. Cervigni, J. A. Rogers, and I. Dvorak, Assessing Low-Carbon Development in Nigeria. 2013

[23] A. Stocchetti and G. Volpato, "In quest for a sustainable motorization the CNG opportunity," Ca' Foscari University, 2010

[24] C. Nwaoha and U. J. Iyoke, "A review on natural gas utilization and cutting carbon emissions: How viable is compressed natural gas for road vehicle fuel ?," J. Energy Technol. Policy, vol. 3, no. 5, pp. 37-46, 2013

[25] J. A. Sonibare and F. A. Akeredolu, "Natural gas domestic market development for total elimination of routine flares in Nigeria's upstream petroleum operations," Energy Policy, vol. 34, pp. 743-753, 2006, doi: 10.1016/j.enpol.2004.07.006.

[26] O. O. Ogunlowo, A. L. Bristow, and M. Sohail, "Developing compressed natural gas as an automotive fuel in Nigeria: Lessons from international markets," Energy Policy, vol. 76, pp. 7-17, 2015, doi: 10.1016/j.enpol.2014.10.025.

[27] M. I. Khan, T. Yasmin, and A. Shakoor, "Technical overview of compressed natural gas (CNG) as a transportation fuel," Renew. Sustain. Energy Rev., vol. 51, pp. 785-797, 2015, doi 10.1016/j.rser.2015.06.053.

[28] Y. Sonia, "An empirical analysis on the adoption of alternative fuel vehicles: the case of natural gas vehicles," Energy Policy, pp. 35:5865 5875, 2007

[29] "CNG national fleet on the rise in Nigeria," NGV Global New, 2016 https://www.ngvglobal.com/blog/cng-national-fleet-on-the-rise-innigeria-1114\#: :text=Nigerian Independent Petroleum Company\%2C NIPCO,NGVs reported in August 2015. (accessed Jun. 06, 2020)

[30] B. Alade, "Vehicles in Nigeria hit 11.7 million," The Guardian, 2018 https://guardian.ng/features/vehicles-in-nigeria-hit-11-7-million/.

[31] P. Bielaczyc, A. Szczotka, and J. Woodburn, "A comparison of exhaust emissions from vehicles fuelled with petrol, LPG and CNG," IOP Conf. Ser. Mater. Sci. Eng., vol. 148, 2016, doi: 10.1088/1757899X/148/1/012060

[32] S. Akbar and M. Kojima, "International experience with CNG vehicles," World Bank Tech. Pap. No. 516., vol. Paper No., pp. 3-6, 2000

[33] D. A. Hagos and E. Ahlgren, "A state-of-the art review on the development of CNG/LNG infrastructure and natural gas vehicles (NGVs)," Chalmers Univ. Technol., 2017.

[34] M. C. Haeng and M. I. Mahmud, "Benefit analysis of CNG as an automobile fuel," CLEAN Technol., vol. 15, no. 1, pp. 1-8, 2009.

[35] L. Dondero and J. Goldemberg, "Environmental implications of converting light gas vehicles: the Brazilian experience," Energy Policy, vol. 33, pp. 1703-1708, 2005 
[36] P. Goyal and Sidhartha, "Present scenario of air quality in Delhi: a case study of CNG implementation," Atmos Env., vol. 37, pp. 5423-5431, 2003.

[37] Z. Wadud and T. Khan, "Air quality and climate impacts due to CNG conversion of motor vehicles in Dhaka , Bangladesh," Environ. Sci. Technol., no. 47, p. 13907-13916, 2013, doi: dx.doi.org/10.1021/es402338b.

[38] G. Pasaoglu, M. Honselaar, and C. Thiel, "Potential vehicle fleet $\mathrm{CO}_{2}$ reductions and cost implications for various vehicle technology deployment scenarios in Europe," Energy Policy, vol. 40, pp. 404-421, 2012, doi: 10.1016/j.enpol.2011.10.025.

[39] C. Ubani and U. Ikpaisong, "Use of CNG as autofuel in Nigeria," Eur. J. Eng. Res. Sci., vol. 3, no. 10, pp. 66-69, 2018, doi: 10.24018/ejers.2018.3.10.668.

[40] O. O. Ogunlowo, A. L. Bristow, and M. Sohail, "A stakeholder analysis of the automotive industry's use of compressed natural gas in Nigeria," Transp. Policy, vol. 53, pp. 58-69, 2017, doi: 10.1016/j.tranpol.2016.09.001.

[41] S. O. Giwa, C. N. Nwaokocha, and B. O. Odufuwa, "Mitigating gas flare and emission footprints via the implementation of natural gas vehicles in Nigeria," Energy Policy, vol. 111, no. April, pp. 193-203, 2017, doi: 10.1016/j.enpol.2017.09.027.

[42] Mariam Harutunian, "Isolated Armenia leads the way in using cleaner car fuel | industryweek," Dec. 05, 2006. https://www.industryweek.com/theeconomy/environment/article/21944288/isolated-armenia-leads-theway-in-using-cleaner-car-fuel (accessed May 27, 2020).

[43] Y. Ebosele, "Use of compressed natural gas vehicle to save Nigeria N654b," Nigerian Guardian, Jul. 2008.
[44] V. Chandra, Fundamentals of Natural Gas: An International Perspective, 2nd Ed. 2017.

[45] N. Leon, "What is the significance of brake thermal efficiency?," 2011 http://www.engineering.com/ask@/qactid/2/qaqid/5503.aspx\#: :text=B rake Thermal Efficiency is defined,a fuel to mechanical energy.

[46] A. Sadi, "Natural Gas : Affordable fuel for operation and support," in Army RD \& A Bulletin - Total Quality Management, 1992.

[47] A. Roychowdhury, "CNG programme in India: The future challenges," Cent. Sci. Environ., pp. 1-37, 2010.

[48] M. I. Khan and T. Yasmin, "Development of natural gas as a vehicular fuel in Pakistan: issues and prospects," J Nat Gas Sci Eng, pp. 17:99$109,2014$.

[49] A. H. Kafood, "CNG Application in Qatar" IPTC 17497, pp. 20-22, 2014.

[50] B. A. Abbanat, "Alternative fuel vehicles: the case of compressed natural gas $(\mathrm{CNG})$ vehicles in California households," Calif. Digit. Libr. - Univ. Calif., 2001.

[51] F. Gabrielle, G. McRae, and P. O’Neill-Vivanco, "The emerging clean transportation workforce: opportunities and recommendations to support the growing alternative fuels industry," Northeast Transp. Work. Cent. Univ. Vermont, 2018.

[52] A. C. Igbojionu, "Development and performance analysis of compressed natural gas as transport fuel for automobiles in Nigeria," Federal University Of Technology Owerri, 2019.

[53] H. Hao, Z. Liu, F. Zhao, and W. Li, "Natural gas as vehicle fuel in China: A review," RenewableandSustainableEnergyReviews, vol. 62, pp. 521-533, 2016, doi: 10.1016/j.rser.2016.05.015. 